\title{
METODE DISKOVERI TERBIMBING (GUIDED DISCOVERY): Konsep dan Aplikasi dalam Pembelajaran Sains MI/SD
}

\author{
Tri Wibowo \\ IAIN Purwokerto, Jawa Tengah \\ triwibowo@iainpurwokerto.ac.id
}

\begin{abstract}
The learning strategy that is highly recommended by experts in science learning activities in elementary school is to use discovery learning strategy. The discovery learning strategy is a learning strategy that provides opportunities for students to discover and construct their own understanding (knowledge) of the learning activities carried out to produce knowledge that is holistic and meaningful. One method of discovery learning strategies that can be used in elementary school science learning activities is using guided discovery methods. The role of educators in science learning activities using guided discovery method is very significant and urgent. These roles include instructors, observers, motivators and evaluators. In order for the application of guided discovery methods to run optimally and according to purpose, educators need to pay attention to various things, including planning and presenting guided learning, application and guided learning techniques and characteristics and potential of students.
\end{abstract}

Keywords: Guided discovery method, elementary school learning.

Abstrak
Dewasa ini strategi pembelajaran yang sangat
direkomendasikan para ahli dalam kegiatan pembelajaran
sains di MI/SD adalah menggunakan strategi pembelajaran
diskoveri. Strategi pembelajaran diskoveri (discovery
learning strategy) merupakan sebuah strategi pembelajaran
yang memberikan kesempatan kepada peserta didik untuk
menemukan dan mengkonstruk sendiri pemahaman


(pengetahuan) dari kegiatan pembelajaran yang dilakukan guna menghasilkan pengetahuan yang holistis dan bermakna (meaningfull). Salah satu metode dari strategi pembelajaran diskoveri yang dapat digunakan dalam kegiatan pembelajaran sains MI/SD adalah menggunakan metode diskoveri terbimbing (guided discovery). Peran pendidik dalam kegiatan pembelajaran sains menggunakan metode diskoveri terbimbing (guided discovery) sangat signifikan dan urgen. Peran itu antara lain sebagai instruktur, observer, motivator dan evaluator. Agar penerapan metode diskoveri terbimbing (guided discovery) dapat berjalan optimal dan sesuai tujuan, pendidik perlu memperhatikan berbagai hal antara lain perencanaan dan penyajian pembelajaran diskoveri terbimbing, aplikasi dan teknik pembelajaran diskoveri terbimbing serta karakteristik dan potensi peserta didik.

Kata Kunci: Metode diskoveri terbimbing, Pembelajaran Pendidikan Dasar (MI/SD).

\section{Pendahuluan}

Kegiatan belajar mengajar merupakan salah satu komponen terpenting dalam sebuah sistem pendidikan. Di dalamnya memuat serangkaian kegiatan yang harus dilakukan oleh pendidik untuk mentransfer ilmu pengetahuan dan nilai (transfer of knowledge and value) kepada peserta didik guna mewujudkan insan yang berpengetahuan dan berakhlak mulia. Salah satu cara untuk mewujudkan pembelajaran yang unggul dan sesuai dengan tujuan yang diharapkan diperlukan sebuah strategi yang tepat dan sesuai.

Pemilihan dan penggunaan metode dalam kegiatan pembelajaran merupakan suatu kegiatan yang harus dilakukan oleh pendidik. Hal ini penting dilakukan guna mendukung dalam pencapaian tujuan pembelajaran agar dapat berjalan secara optimal dan tepat sasaran. Pemilihan dan penggunaan metode pembelajaran harus disesuaikan dengan berbagai aspek yang melingkupinya, seperti kesesuaian dengan tujuan pembelajaran, karakteristik materi ajar, kemampuan peserta didik, dan ketersediaan media pendukung dalam kegiatan pembelajaran yang akan dilakukan. 
Strategi pembelajaran diskoveri (discovery learning strategy) merupakan salah satu strategi yang paling baik untuk mendukung ketercapaian tujuan yang diharapkan tersebut. Strategi pembelajaran diskoveri paling baik dilaksanakan dalam kelompok belajar yang kecil. Namun dapat juga dilaksanakan dalam kelompok belajar yang besar. Strategi pembelajaran diskoveri dapat memberikan manfaat yang besar bagi kemajuan peserta didik. Manfaat-manfaat tersebut antara lain dapat berupa meningkatkan kepercayaan peserta didik, melibatkan peserta didik secara aktif dalam pembelajaran, menggunakan cara yang sesuai dalam memahami pelajaran Sains sesuai dengan apa yang dilakukan para Sainstis untuk mendapatkan dan membangun sebuah pengetahuan yang bermanfaat.

Dalam penerapan strategi pem-belajaran diskoveri dapat menggunakan berbagai metode pembelajaran yang sesuai. Metode pembelajaran yang termasuk bagian dari strategi pembelajaran diskoveri antara lain yaitu metode diskoveri terbimbing, diskoveri bebas dan diskoveri bebas yang dimodifikasi. Artikel ini akan memaparkan salah satu metode dari strategi pembelajaran diskoveri yaitu metode diskoveri terbimbing (guided discovery) dan proses penerapanya dalam pembelajaran sains.

\section{Pembahasan}

\section{Definisi dan Fungsi Metode Diskoveri Terbimbing (Guided Discovery)}

Metode diskoveri terbimbing (guided discovery) memiliki peranan yang sangat penting dalam kegiatan pembelajaran, antara lain sebagai wahana peserta didik untuk memahami materi melalui kegiatan yang menyenangkan atas petunjuk pendidik. Metode diskoveri terbimbing (guided discovery) adalah suatu rangkaian prosedur pembelajaran yang melibatkan proses mental peserta didik dengan mengasimilasikan suatu konsep atau prinsip dalam suatu kegiatan pembelajaran yang dilakukan atas petunjuk dari pendidik (guru). Adapun yang dimaksud dengan proses mental seperti: mengamati, mencerna, 
memahami, menggolongkan, memprediksi, menjelaskan, mengukur, menarik kesimpulan dan sebagainya (Roestiyah, 1991: 21-22).

Beberapa contoh yang termasuk konsep antara lain meliputi panas, kelembaban, elastisitas, gaya, dan lain sebagainya. Kemudian yang termasuk contoh dari prinsip antara lain ialah: logam apabila dipanaskan akan mengembang, air apabila dipanaskan mendidih pada suhu $100^{\circ} \mathrm{C}$ dan seterusnya. Dalam metode pembelajaran diskoveri terbimbing (guided discovery), peserta didik dilatih untuk menemukan sendiri atau mengalami proses mental secara langsung dan pendidik hanya membimbing dan memberikan arahan dalam kegiatan pembelajaran yang sedang berlangsung tersebut.

Adapun fungsi dari metode diskoveri terbimbing (guided discovery) antara lain sebagai berikut (Hanafiah \& Suhana, 2010: 78).

a. Peserta didik membangun komitmen (commitment building) untuk belajar, yang diwujudkan dalam bentuk ketertiban, kesungguhan, kemandirian dan loyalitas terhadap pencarian dan penemuan pengetahuan dalam kegiatan pembelajaran.

b. Peserta didik membangun sikap aktif, kreatif dan inovatif dalam proses pembelajaran dalam rangka mencapai tujuan pembelajaran yang telah ditetapkan.

c. Peserta didik membangun sikap percaya diri (self confidence) dan terbuka (openess) terhadap temuannya dalam kegiatan pembelajaran yang telah dilakukan.

\section{Jenis Pengetahuan dan Metode Mengajar}

Dasar pemikiran pembelajaran diskoveri didasarkan pada Bruner dan Papert. Dalam penerapan metode pembelajaran diskoveri terbimbing (guided discovery), juga harus memperhatikan kesesuaian metode tersebut dengan jenis pengetahuannya. Kesesuaian metode dengan jenis pengetahuan penting diselaraskan guna pencapaian tujuan pembelajaran yang sesuai dan tepat sasaran. Penggunaan strategi diskoveri dalam batas-batas tertentu sangat baik untuk peserta didik di kelas rendah (Hamdani, 2011: 185). Hal ini mengindikasikan

Elementary Vol. 7 No.1 Januari-Juni 2019 
bahwa strategi diskoveri memang cocok untuk diterapkan dalam kegiatan pembelajaran di jenjang pendidikan dasar (MI/ SD). Pendidikan dasar (MI/SD) sangat memperhatikan metode mengajar yang cocok guna tercapinya tujuan pendidikan secara optimal dan tepat sasaran.

Menurut Piaget sebagaimana diuraikan oleh Kamii \& De Vries dalam Ann C. Howe, jenis pengetahuan dikategorikan menjadi empat macam yaitu sebagai berikut (Howe \& Jones, 1993: 173-174).

\section{a. Pengetahuan Kemampuan Sosial (Social Arbitrary Knowledge)}

Pengetahuan kemampuan sosial (social arbitrary knowledge) merupakan sebuah pengetahuan yang terkait dengan kemampuan individu (panca indra) dalam memutuskan cara, menentukan waktu dan lain sebagainya dalam hal mendapatkan pengetahuan. Adapun yang termasuk dalam kategori jenis pengetahuan kemampuan sosial (social arbitrary knowledge) antara lain ialah aturan pembelajaran, tahapan sebuah prosedur, adat dan konvensi, nama, simbol dan aspek mekanis penggunaan bahasa. Jenis pengetahuan ini tidak terlalu memerlukan kedalaman pemahaman dan dapat dihafalkan. Strategi pembelajaran langsung (direct instruction strategy) merupakan salah satu strategi pembelajaran yang paling tepat digunakan untuk membelajarkan jenis pengetahuan ini. Adapun contoh pengetahuan kemampuan sosial meliputi: cara menggunakan alat ukur, berbagai fakta mengenai Matematika dasar, kata-kata dan musik dari lagu baru serta lain-lainnya.

\section{b. Pengetahuan Fisik (Physical Knowledge)}

Pengetahuan fisik (physical knowledge) merupakan sebuah pengetahuan yang diperoleh dari pengalaman langsung melalui benda-benda konkret. Jenis pengetahuan ini, diperoleh melalui proses pengamatan (observasi) terhadap suatu benda menggunakan panca indra. Cara terbaik untuk membelajarkan pengetahuan fisik (physical knowledge) adalah menggunakan kegiatan praktik lapangan (hands on). Adapun contoh yang termasuk dari pengetahuan fisik antara lain meliputi merasakan dan mendengarkan suara kotak misteri (musik, materi, dll), 
pisang matang berwarna kuning dan baunya, pencampuran baking soda dan cuka, serta lain sebagainya (Howe \& Jones, 1993: 174).

\section{c. Pengetahuan Logis (Logical Knowledge)}

Pengetahuan logis (logical knowledge) merupakan jenis pengetahuan yang meliputi konsep, generalisasi, kesimpulan dan ide-ide yang berasal dari berpikir dan pengamatan. Pengetahuan logis diperoleh melalui proses berpikir dan mengamati (tidak dihafal). Meskipun kata-kata yang digunakan dalam pembelajaran pengetahuan logis untuk menggambarkan konsep-konsep ini dapat dihafal, namun cara belajar tersebut akan menghasilkan pengetahuan yang dangkal dan terputus dari makna operasional dalam pemikiran jenis pengetahuan ini.

Metode pembelajaran yang tepat untuk jenis pengetahuan ini adalah menggunakan metode diskusi dengan keterlibatan tinggi yang mengarah kepada pemikiran kritis dan refleksi tentang pengetahuan fisik. Diskusi tersebut dapat dilakukan dalam kelompok kecil teman sebangku, atau membentuk kelompok-kelompok dalam sebuah kelas dengan bimbingan dan arahan dari guru (pendidik). Adapun contoh pengetahuan logis meliputi antara lain yaitu: rangkaian listrik, hukum benda mengapung, bagaimana pesawat agar tidak terjatuh dan lain sebagainya (Howe \& Jones, 1993: 174- 175).

\section{d. Pengetahuan Interaktif Sosial (Social Interactive Knowledge)}

Pengetahuan interaktif sosial (social interactive knowledge) merupakan sebuah jenis pengetahuan yang diperoleh melalui interaksi dengan orang lain, termasuk bergaul dengan orang lain yang mampu bekerja bersama (kerja kelompok) dalam suatu kegiatan. Jenis pengetahuan ini yang dipelajari melalui interaksi dengan orang lain. Hal ini (social interactive knowledge) berkaitan erat dengan pengetahuan kemampuan sosial (social arbitrary knowledge), tetapi lebih berkaitan dengan etika kelompok. Sedangkan pengetahuan kemampuan sosial lebih berkaitan dengan informasi verbal. Cara membelajarkan pengetahuan jenis ini adalah menggunakan metode pengalaman kelompok. Adapun contoh pengetahuan interaktif sosial antara lain yaitu 
mempertimbangkan perasaan orang lain, menghargai pendapat orang lain, bekerjasama dengan orang lain dan sebagainya (Howe \& Jones, 1993: 175).

\section{Perencanaan dan Penyajian Pembelajaran Diskoveri Terbimbing}

Perencanaan dan penyajian pem-belajaran diskoveri terbimbing (guided discovery) merupakan suatu proses penyusunan dan pelaksanaan pembelajaran diskoveri terbimbing agar berjalan secara optimal untuk mencapai tujuan yang telah ditetapkan sebelumnya (Sa'ud, 2005: 5).

Pembelajaran diskoveri terbimbing (guided discovery) adalah sebuah kegiatan proses pembelajaran yang melibatkan peserta didik untuk mengkonstruksi pengetahuannya sendiri melalui proses mental. Aspek motivasi merupakan komponen penting yang harus ada dalam pembelajaran diskoveri terbimbing. Aspek motivasi digunakan untuk mencari sesuatu yang berguna bagi peserta didik dalam kegiatan pembelajaran yang menggunakan metode ini. Alasan yang paling urgen untuk melakukan pembelajaran dengan metode diskoveri terbimbing (guided discovery) adalah terletak lebih kepada proses kognitif, afektif dan domain sosial dibandingkan dengan domain kognitif konten (cognitive content domain). Pengembangan aspek kognitif, afektif dan sosial merupakan unsur-unsur terpenting pembentuk spiritualitas, kepribadian dan intelektual peserta didik yang berguna bagi kehidupannya pada masa kini dan mendatang.

Adapun struktur perencanaan dan penyajian kegiatan pembelajaran diskoveri terbimbing (guided discovery) antara lain sebagai berikut (Howe \& Jones, 1993: 180- 181).

\section{a. Tujuan Pembelajaran (Performance Objective)}

Tujuan pembelajaran merupakan pernyataan yang memuat tentang kompetensi yang harus dicapai peserta didik setelah melakukan kegiatan pembelajaran. Kompetensi tersebut meliputi tiga ranah berupa pengetahuan (kognitif), sikap (afektif) dan psikomotorik (keterampilan). Ketiga ranah dikembangkan dalam kegiatan pembelajaran guna menciptakan profil peserta 
didik yang berintelektual, berakhlak mulia dan bermanfaat bagi sesama dalam kehidupan bermasyarakat.

\section{b. Bahan (Materials)}

Bahan (materials) adalah daftar bahan/materi yang harus dipersiapkan untuk kegiatan pembelajaran yang akan dilakukan. Dengan kata lain, bahan (materials) merupakan sebuah sarana yang digunakan untuk mencapai tujuan pembelajaran yang telah ditetapkan sebelumnya (Prastowo, 2015: 194). Bahan (materials) sangat urgen untuk disiapkan dalam sebuah kegiatan pembelajaran guna mendukung tercapainya tujuan secara efektif dan efisien. Penyiapan bahan (materials) harus memperhatikan berbagai aspek yang melingkupinya seperti ketersediaan media/alat peraga, biaya, sumber daya manusia dan keterkaitan dengan tujuan yang hendak dicapai.

\section{c. Kegiatan Pembelajaran (Learning Activities)}

1. Motivasi (Motivation)

Motivasi ialah suatu usaha yang digunakan untuk meningkatkan kegiatan proses pembelajaran guna mencapai tujuan pembelajaran agar dapat berjalan secara optimal (Prawira, 2013: 319-320). Dalam kegiatan motivasi, pendidik melakukan berbagai tindakan yang dapat meningkatkan minat dan memfokuskan perhatian peserta didik untuk semangat, giat dan antusias dalam mengikuti kegiatan pembelajaran yang akan dilakukan. Kegiatan-kegiatan itu dapat berupa memberi pemahaman pada peserta didik tentang pentingnya menguasai ilmu pengetahuan, bertanya jawab, bernyanyi dan lain sebagainya.

2. Pengumpulan Data (Data Collection)

Pengumpulan data (data collection) merupakan suatu kegiatan mengumpulkan informasi tentang situasi yang sedang diamati dalam sebuah kegiatan pembelajaran. Informasi yang dicatat berupa daftar kata-kata yang menggambarkan objek/peristiwa/angka yang mewakili pengukuran dari kegiatan pengamatan 
yang telah dilakukan (pemerolehan pengetahuan fisik). Data dapat dikumpulkan dalam bentuk rekaman suara, catatan tertulis, gambar dan lain sebagainya. Data adalah suatu catatan (informasi) yang diperoleh dari pengamatan melalui panca indra (Howe \& Jones, 1993: 181-182).

3. Pengolahan Data (Data Processing)

Data yang telah dikumpulkan, digunakan oleh peserta didik dibawah bimbingan pendidik untuk diproses menjadi sebuah informasi (data) yang bermakna untuk mendapatkan sebuah kesimpulan, spekulasi, generalisasi dan berpikir tingkat tinggi lainnya (pembangunan pengetahuan logis). Proses pengolahan data (data processing) dilakukan dengan metode diskusi terbimbing (guided discussion). Kegiatan diskusi terbimbing digunanakan untuk membantu peserta didik berpikir tentang pengamatan yang telah dilakukannya dan menghubungkan pengamatan itu secara logis dengan pengetahuan yang telah dimilikinya.

4. Penutupan (Closure)

Penutupan (closure) merupakan kegiatan yang dilakukan pendidik untuk mengakhiri proses kegiatan pembelajaran yang dapat dilaksanakan dalam bentuk peninjauan, meringkas dan menarik kesimpulan, refleksi, umpan balik serta tindak lanjut (Rusman, 2012: 6-7). Kegiatan penutupan mempunyai tujuan agar pembelajaran yang telah dilakukan dapat tercerna secara baik oleh peserta didik.

\section{e. Penilaian (Appraisal)}

Penilaian merupakan sutu kegiatan yang dilakukan untuk mengetahui telah sejauh mana peserta didik memahami materi pelajaran yang telah dipelajarinya yang hasil kegiatan tersebut dituangkan dalam data berbentuk kuantitatif (Arikunto \& Jabar, 2009: 1-2). Dengan adanya kegiatan penilaian (appraisal), pendidik dapat mengetahui kekurangan, kendala dan kesulitan yang dialami peserta didik maupun dirinya untuk menjadibahan 
perbaikan yang diharapkan dapat meningkatkan pelayanan dan proses pembelajaran yang berkualitas dan sesuai dengan tujuan yang hendak dicapai.

\section{Contoh Pelaksanaan pembelajaran Diskoveri Terbimbing dalam Pembelajaran Sains MI/SD}

Berikut ini adalah contoh pelaksanaan pembelajaran diskoveri terbimbing (guided discovery) dalam pembelajaran sains di jenjang pendidikan dasar (MI/SD) untuk kelas rendah/ kelas I-III (Howe \& Jones, 1993: 183-184).

\section{a. Topik}

Mengenal mealworm (larva kumbang tenebrio molitor/ jenis kumbang hitam).

\section{b. Tujuan Pembelajaran}

Pada akhir kegiatan pembelajaran yang telah dilakukan, peserta didik dapat:

1. Menunjukan bagian-bagian dari mealworm.

2. Mendeskripsikan bentuk dan perilaku dari mealworm.

c. Bahan

Untuk setiap peserta didik mendapatkan 1 (satu) mealworm di cangkir kertas yang digunakan sebagai bahan pengamatannya.

\section{d. Kegiatan Pembelajaran}

1. Motivasi

Pendidik menggunakan bahan pengamatan (mealworm) sebagai media untuk memberikan motivasi kepada peserta didik guna gemar belajar, semangat dan melakukan kegiatan-kegiatan yang bermanfaat. Misal, "lihatlah apa yang ada di tangan pak guru". Kegiatan tersebut dilakukan untuk memfokuskan peserta didik pada objek yang menjadi materi pokok pada proses pembelajaran yang akan dilakukan oleh peserta didik.

2. Pengumpulan Data

a. Pendidik memberikan arahan untuk mengumpulkan 
data tentang mealworm (meminta peserta didik mengamati mealworm secara seksama baik anatomi maupun perilakunya).

b. Pendidik memberikan waktu selama 15 menit untuk mengumpulkan data tentang mealworm (kegiatan pengamatan mealworm pesdik).

c. Pendidikmemintapesertadidikuntukmengumpulkan mealwormnya.

3. Pengolahan Data

a. Pendidik memberikan pertanyaan stimulus untuk memancing pengetahuan yang didapat dari kegiatan pengamatan yang telah dilakukannya itu. Seperti, apa yang kalian ketahui tentang mealworm seperti bentuk, warna, makanannya dan lain sebagainya.

b. Pendidik menulis beberapa ide pokok tentang mealworm di kertas grafik/papan tulis.

c. Pendidik meminta peserta didik untuk mengadakan diskusidengantemannya terkaithasildaripengamatan yang telah dilakukannya.

4. Penutupan

Dalam kegiatan penutupan, pendidik bersama peserta didik merangkum, membuat kesimpulan dan mengklarifikasi hasil temuan peserta didik dalam kegiatan pengamatannya mengenai mealworm dan berbagai hal yang terkait dengannya.

\section{e. Penilaian}

Kegiatan pembelajaran yang dilakukan ini menggunakan penilaian dalam bentuk observasi berupa daftar pengamatan terhadap peserta didik dalam mengamati mealworm dan seluk beluknya. Observasi (pengamatan) merupakan salah satu alat penilaian yang digunakan untuk mengukur proses atau tingkah laku individu dalam suatu kegiatan yang dapat diamati, baik dalam situasi yang sebenarnya maupun buatan/ dikondisikan (Sudjana, 2005: 84-85). Kegiatan penilaian dalam proses pembelajaran ini dilakukan untuk mengetahui tingkat 
pemahaman, sikap dan keterampilan peserta didik dalam materi pokok tentang mealworm.

\section{Elemen-elemen Dasar dalam Pembelajaran Kooperatif}

Pembelajaran kooperatif merupakan serangkaian kegiatan pembelajaran yang dilakukan oleh peserta didik dalam suatu kelompok-kelompok tertentu yang mempunyai latar belakang kemampuan akademis, jenis kelamin, ras atau suku yang berbeda guna mencapai tujuan pembelajaran yang telah dirumuskan (Sanjaya, 2010: 194).

Kelompok pembelajaran secara kooperatif sebaiknya dibentuk oleh pendidik. Pembentukan kelompok dalam pembelajaran kooperatif dilaksanakan dengan cara menugaskan peserta didik untuk mengelompok menjadi satu grup. Tiaptiap grup sebaiknya terdiri atas empat atau lima orang. Pengelompokkan grup (kelompok) harus mempertimbangkan berbagai hal (heterogenitas), antara lain yaitu adanya laki-laki dan perempuan dalam tiap kelompok, tingkat kecerdasan, etnis, ras serta minat dan gaya belajar dari peserta didik. Dari hasil penelitian menunjukkan bahwa efek dari penggunaan pembelajaran kooperatif adalah keefektifannya dalam menumbuhkan/ meningkatkan hubungan kerjasama yang lebih baik antara individu dalam suatu kegiatan pembelajaran.

Dalam pembelajaran kooperatif, pendidik mulai dengan menjelaskan proses pembelajaran dan membentuk kelompok. Setiap kelompok diberikan masalah atau tugas serta pendidik melakukan pemantauan dan bimbingan selama proses pembelajaran kooperatif berlangsung. Adapun pedoman untuk pembentukan kelompok dalam pembelajaran kooperatif memiliki empatelemen dasar. Elemen dasar dalam pembelajaran kooperatif yaitu sebagai berikut (Howe \& Jones, 1993: 194-195).

\section{a. Saling Ketergantungan Positif}

Peserta didik diharapkan dapat merasakan bahwa kesuksesan pembelajaran kooperatif berada pada kesaling bergantungan antar anggota kelompok dalam menyelesaikan tugas atau masalah yang diberikan oleh pendidik. 


\section{b. Interaksi Antar Individu}

Persepsi saling ketergantungan antar individu mengarah kepada kegiatan diskusi, penyampaian argumen/pendapat, dan kegiatan persuasif. Kegiatan seperti ini merupakan interaksi yang menghasilkan pembelajaran yang bermakna.

\section{c. Tanggung Jawab Individu}

Setiap anggota kelompok bertanggungjawab untuk berpartisipasi dan aktif dalam kegiatan pembelajaran. Partisipasi peserta didik dalam kegiatan pembelajaran merupakan suatu proses untuk mendapatkan pengetahuan melalui kegiatan belajar secara berkelompok.

\section{d. Penggunaan Keterampilan Sosial yang Tepat}

Peserta didik harus diajarkan keterampilan sosial (social skills) yang diperlukan untuk bekerjasama dan termotivasi untuk menggunakannya dalam kegiatan pembelajaran.

\section{Pengaruh Usia dan Kedewasaan dalam Metode Mengajar}

Menurut Piaget, tahapan perkembangan berpikir anakdibagi menjadi empat tahap yaitu tahap sensorimotorik (0-2 tahun), tahap praoperasional (2-7 tahun), tahap operasional konkret (7-11 tahun) dan tahap operasional formal/ 11 tahun sampai dewasa (Schunk, 2012: 332). Dari tahapan perkembangan berpikir menurut Piaget tersebut, dapat ditarik sebuah pengertian bahwa dalam sebuah rangkaian proses pembelajaran (misal metode pembelajaran) harus memperhatikan tentang usia dan kedewasaan guna pencapaian tujuan pembelajaran dapat terlaksana secara optimal.

Usia dan kedewasaan peserta didik merupakan salah satu komponen yang harus diperhatikan ketika seorang pendidik akan memilih dan menggunakan metode pembelajaran. Penggunaan metode pembelajaran yang sama pada tingkat usia dan kedewasaan berbeda dalam pengaplikasiannya pun akan berbeda. Misal, untuk peserta didik pada usia pendidikan dasar (MI/SD), misal dalam penerapan metode diskoveri terbimbing (guided discovery) proses dan langkah pembelajarannya akan 
lebih sederhana jika dibandingkan dengan peserta didik pada jenjang pendidikan tingkat lanjutan (MTs/ SMP).

Perbedaan utama mengenai pengaruh usia dan kedewasaan dalam metode pembelajaran diskoveri terbimbing (guided discovery) terletak pada pengolahan data dalam proses pembelajaran. Peserta didik di tingkat pendidikan dasar (MI/ SD) mulai dilatih untuk diskusi dengan cara yang sederhana, kemudian dapat berlanjut ke keterampilan berpikir ke tingkat yang lebih tinggi, seperti menyimpulkan, memprediksi, bahkan perencanaan percobaan. Penggunaan keterampilan berpikir merupakan suatu proses untuk mendapatkan ilmu pengetahuan (Howe \& Jones, 1993: 196).

\section{Hal-hal yang Perlu Diperhatikan dalam Penerapan Metode Diskoveri Terbimbing (Guided Discovery)}

Berbagai hal yang harus diperhatikan dalam penerapan metode diskoveri terbimbing (guided discovery) antara lain yaitu sebagai berikut (Howe \& Jones, 1993: 196-197).

a. Pengelolaan atau peninjauan tingkat tingkah laku peserta didik.

b. Peserta didik diharapkan menemukan sendiri konsep dari suatu hal.

c. Pendidik memberikan arahan dan prosedur pembelajaran yang jelas untuk kegiatan pembelajaran yang akan dilakukan.

d. Memperkenalkan kosakata baru seperlunya yang sesuai dengan materi yang sedang dipelajari oleh peserta didik.

e. Memberikan keleluasaan kepada peserta didik untuk bekerja secara produktif dalam kegiatan pembelajaran.

f. Menggunakan bahasa yang sopan, lembut dan mudah dimengerti oleh peserta didik.

g. Selamakegiatan pengolahan data darikegiatan pembelajaran, pendidik meminta kepada peserta didik untuk melaporkan data yang telah dikumpulkan. Hal ini dilakukan untuk mengetahui telah sejauh mana pengamatan yang dilakukan peserta didik terhadap objek tertentu.

h. Bila memungkinkan, meminta peserta didik untuk 
melanjutkan diskusi diluar proses pembelajaran. Hal ini dilakukan untuk memberikan kesempatan kepada peserta didik untuk memahami materi pembelajaran secara lebih mendalam dan komprehensif.

\section{Penerapan dan Teknik Diskoveri Terbimbing (Guided Discovery)}

Penerapan dan teknik diskoveri terbimbing (guided discovery) merupakan suatu bentuk implementasi dan cara yang digunakan oleh pendidik agar kegiatan pembelajaran dapat berjalan dengan baik melalui penggunaan diskoveri terbimbing guna mencapai tujuan yang telah ditetapkan sebelumnya (tujuan pembelajaran).

Penerapan dan teknik diskoveri terbimbing (guided discovery) antara lain sebagai berikut ini.

\section{a. Pengelolaan Perilaku dan Materi Ajar}

Pengelolaan perilaku dan materi ajar merupakan suatu bentuk penerapan dan pengelolaan sejumlah perilaku dan materi ajar yang harus dilakukan oleh pendidik dan peserta didik dalam suatu kegiatan pembelajaran. Kegiatan ini penting dilakukan guna mendukung ketercapaian kompetensi peserta didik secara optimal pada suatu kegiatan pembelajaran yang dilakukannya. Kompetensi merupakan kemampuan minimal yang harus dimiliki oleh peserta didik setelah mengikuti kegiatan pembelajaran dalam kurun waktu dan jenjang tertentu.

Kegiatan pengelolaan perilaku dan materi ajar antara lain meliputi: pengaturan tingkat kegaduhan selama proses pembelajaran, penggunaan psikologi pembelajaran yang sesuai dengan tahap perkembangan peserta didik untuk usia MI/SD, penggunaan isyarat nonverbal secara optimal, persebaran tugas yang merata terkait materi ajar yang dipelajari, mengontrol kegiatan pembelajaran agar senantisa dalam keadaan kondusif, dan memberikan tugas rumah (PR) kepada peserta didik yang melibatkan peran orang tua (Howe \& Jones, 1993: 242-245). Pelibatan orang tua dalam kegiatan pembelajaran penting dilakukan sebagai sebuah wujud partisipasi aktif dan kepedulian 
konkret wali murid dalam mensukseskan pendidikan bagi anak-anaknya.

\section{b. Penggunaan Teknik Verbal}

Penggunaan teknik verbal adalah suatu bentuk penerapan berbagai cara penggunaan bahasa lisan dalam kegiatan pembelajaran menggunakan metode diskoveri terbimbing (guided discovery) yang mengarah kepada ketercapaian tujuan pembelajaran agar dapat berjalan dengan baik dan mencapai tujuan.

Teknik verbal merupakan bagian kegiatan komunikasi. Dalam kegiatan komunikasi verbal digunakan bahasa, baik bahasa lisan maupun tulisan yang melibatkan dua orang atau lebih yang di dalamnya terjadi pertukaran informasi dalam rangka mencapai tujuan pembelajaran yang hendak dicapai (Majid, 2013: 285).

Teknik verbal dalam metode diskoveri terbimbing (guided discovery)terdiriataspemberianarahankepadapesertadidikdalam kegiatan pembelajaran, pendidik memfasilitasi pengumpulan data dalam kegiatan praktikum yang dilakukan oleh peserta didik, adan ya kegiatan diskusi dalam pengolahan data dalam kegiatan praktikum peserta didik, memberikan kesempatan bertanya seluas-luasnya kepada peserta didik, pengelolaan waktu yang efektif, memberikan pujian, dan melakukan kegiatan pembelajaran secara interaktif guna memecahkan masalah yang dihadapi (Howe \& Jones, 1993: 245- 248).

\section{c. Pengembangan Bahasa}

Pengembangan bahasa adalah suatu bentuk pengelolaan bahasa yang dilakukan oleh pendidik guna menunjang kegiatan pembelajaran dapat berjalan secara optimal dengan merencanakandanmenggunakanberbagaimacambentukbahasa (lisan maupun tulisan) agar peserta didik dapat memperoleh pengetahuan, sikap dan perilaku yang sesuai dengan tujuan pembelajaran yang telah ditetapkan sebelumnya.

Pengembangan bahasa merupakan bagian integral dari kegiatan pembelajaran ilmu pengetahuan. Kegiatan 
pengembanganbahasa padametodediskoveriterbimbing(guided discovery) terdiri atas: melatih komunikasi secara lisan yang terkait keterampilan menyampaikan pendapat dalam kegiatan pembelajaran, penggunaan bahasa yang tepat, pengenalan istilah baru yang terkait materi ajar, serta menggunakan bahasa yang komunikatif dan mudah dipahami sesuai dengan tahap perkembangan peserta didik (Howe \& Jones, 1993: 257-259).

\section{Kelebihan dan Kekurangan Metode Diskoveri Terbimbing}

\section{a. Kelebihan Metode Diskoveri Terbimbing (Guided Discovery)}

Setiap metode pembelajaran pasti memiliki kelebihan dan kekurangan masing-masing. Maka dari itu, kita perlu mengetahui berbagai kelebihan dan kekurangan metode pembelajaran termasuk metode diskoveri terbimbing (guided discovery), guna mengoptimalkan kelebihan serta meminimalisir kekurangannya dalam rangka mencapai tujuan yang hendak dicapai dalam sebuah kegiatan pembelajaran.

Berikut ini kelebihan metode diskoveri terbimbing (guided discovery) antara lain sebagai berikut (Suryosubroto, 2009: 185-186).

1. Membantu peserta didik untuk mengembangkan diri, kesiapan belajar serta penguasaan keterampilan dalam proses kognitifnya. Proses kognitif yang berjalan baik akan menciptakan kegiatan pembelajaran yang efektif dan efisien.

2. Peserta didik memperoleh pengetahuan secara individual sehingga pengetahuan yang didapatnya menjadi bermakna (meaningfull).

3. Dapat membangkitkan motivasi dan semangat belajar peserta didik untuk belajar lebih giat.

4. Memberikan peluang untuk berkembang dan maju sesuai dengan kemampuan dan minat masing-masing peserta didik.

5. Memperkuat dan menambah kepercayaan diri peserta didik dengan proses menemukan sendiri pengetahuannya karena pembelajaran yang dilakukan 
berpusat pada peserta didik (student centered) dengan peran guru yang sangat terbatas (membimbing dan mengarahkan).

6. Membantu perkembangan peserta didik menuju skeptisisme yang sehat untuk menemukan kebenaran akhir dan mutlak.

b. Kekurangan Metode Diskoveri Terbimbing (Guided Discovery)

Beberapa kekurangan metode diskoveri terbimbing (guided discovery) antara lain sebagai berikut (Suryosubroto, 2009: 186-187).

1. Peserta didikharus memiliki kesiapan dankematangan mental, artinya bahwa peserta didik harus mampu dan berkeinginan untuk mengetahui keadaan lingkungan sekitarnya dengan baik.

2. Tidak cocok digunakan untuk kelas yang gemuk.

3. Pendidik dan peserta didik yang sudah terbiasa dengan kegiatan pembelajaran gaya lama maka tidak tertarik dengan metode ini.

4. Mengajar dengan metode diskoveri terbimbing (mungkin) akan dipandang sebagai sesuatu yang terlalu mementingkan pemerolehan pengetahuan dan kurang memperhatikan diperolehnya sikap dan keterampilan dan sebuah proses pembelajaran. Sedangkan sikap dan keterampilan diperlukan untuk memperoleh pengetahuanatau sebagai perkembangan emosional sosial secara keseluruhan.

5. Dalam beberapa disiplin ilmu (semisal Sains) untuk fasilitas/media pembelajaran yang dibutuhkan untuk mencoba ataupun mempraktikkan ide-ide mungkin tidak ada/sulit didapat.

\section{Simpulan}

Metode diskoveri terbimbing (guided discovery method) adalah suatu rangkaian prosedur pembelajaran yang melibatkan proses mental peserta didik dengan mengasimilasikan suatu konsep atau prinsip dalam suatu kegiatan pembelajaran yang dilakukan atas petunjuk dari pendidik (guru). Adapun yang 
dimaksud dengan proses mental antara lain yaitu: mengamati, mencerna, mengerti, menggologkan, memprediksi, menjelaskan, mengukur, menarik kesimpulan dan sebagainya.

Menurut Piaget sebagaimana diuraikan oleh Kamii \& De Vries dalam Ann C. Howe, jenis pengetahuan dikategorikan menjadi empat macam yaitu pengetahuan kemampuan sosial (social arbitrary knowledge), pengetahuan fisik (physical knowledge), pengetahuan logis (logical knowledge) dan pengetahuan interaktif sosial (social interactive knowledge). Adapun format umum perencanaan dan penyajian pembelajaran diskoveri terbimbing (guided discovery learning) antara lain yaitu tujuan pembelajaran (performance objective), bahan pembelajaran (materials), aktivitas pembelajaran (learning activities) yang terdiri atas motivasi, pengumpulan data, pemrosesan data dan penutupan, serta penilaian (appraisal).

Kelompok pembelajaran secara kooperatif sebaiknya dibentuk oleh pendidik. Pembentukan kelompok dalam pembelajaran kooperatif dilaksanakan dengan cara menugaskan peserta didik untuk mengelompok menjadi satu grup. Tiaptiap grup sebaiknya terdiri atas empat atau lima orang. Pengelompokan grup (kelompok) harus mempertimbangkan berbagai hal (heterogenitas), antara lain yaitu adanya laki-laki dan perempuan dalam tiap kelompok, tingkat kecerdasan, etnis, ras serta minat dan gaya belajar dari peserta didik.

\section{Daftar Pustaka}

Arikunto, Suharsimi \& Cepi Safruddin Abdul jabar. 2009. Evaluasi Program Pendidikan: Pedoman Teoretis Praktis Bagi Mahasiswa dan Praktisi Pendidikan. Jakarta: Bumi Aksara.

Hamalik, Oemar. 2010. Perencanaan Pengajaran Berdasarkan Pendekatan Sistem, Cet. ke-9. Jakarta: Bumi Aksara.

Hamdani. 2011. Strategi Belajar Mengajar. Bandung: Pustaka Setia. 


\section{4| Tri Wibowo}

Hanafiah, Nanang \& Cucu Suhana. 2010. Konsep Strategi Pembelajaran, Cet. ke-2. Bandung: Refika Aditama.

Howe, Ann C. \& Linda Jones. 1993. Engaging Children in Science. New York: Macmillan Publishing Company.

Majid, Abdul. 2013. Strategi Pembelajaran. Bandung: Remaja Rosdakarya.

NK, Roestiyah. 1991. Strategi Belajar Mengajar: Salah Satu unsur Pelaksanaan Strategi Belajar Mengajar dan Teknik Penyajian, Cet. ke-4. Jakarta: Rineka Cipta.

Prastowo, Andi. 2015. Menyusun Rencana Pelaksanaan Pembelajaran (RPP) Tematik Terpadu: Implementasi Kurikulum 2013 untuk SD/ MI. Jakarta: Kencana.

Prawira, Purwa Atmaja. 2013. Psikologi Pendidikan dalam Perspektif Baru. Yogyakarta: Ar-Ruzz Media.

Rusman. 2012. Model-model Pembelajaran: Mengembangkan Profesionalisme Guru. Jakarta: Rajawali Pers.

Sa'ud, Udin Saefudin. 2005. Perencanaan Pendidikan. Bandung: Remaja Rosdakarya.

Sanjaya, Wina. 2010. Perencanaan dan Desain Sistem Pembelajaran, Cet. ke-3. Jakarta: Kencana.

Schunk, Dale H. 2012. Teori-teori Pembelajaran: PerspektifPendidikan, terj. Eva Hamdiah \& Rahmat Fajar. Yogyakarta: Pustaka Pelajar.

Sudjana, Nana. 2005. Penilaian Hasil Proses Belajar Mengajar. Bandung: Remaja Rosdakarya.

Suryosubroto, B. 2009. Proses Belajar Mengajar di Sekolah: Wawasan Baru, Beberapa Metode Pendukung dan Beberapa Komponen Layanan Khusus. Jakarta: Rineka Cipta. 